\title{
Sınıf Öğretmeni Adaylarının Girişimcilik Becerisine İlişkin Yeterlik Algıları ${ }^{1}$
}

\section{Self-Efficacy Perception of Pre-service Class Teachers about Entrepreneurship Skill}

\author{
Şengül S. ANAGÜN ${ }^{2} \quad$ Nurhan ATALAY ${ }^{3}$
}

Başvuru Tarihi: 21.10.2016

Yayına Kabul Tarihi: 28.03.2017

DOI: $10.21764 /$ efd.57979

Özet: Eğitim programlarında 21. yüzyıl becerilerinin ve yaşam becerilerinin altında yer alan "girişimcilik" becerisine sahip bireylerin yetiştirilmesi hemen hemen tüm ülkelerin eğitimlerinde amaçlanmaktadır. Eğitim yoluyla öğrencilerin girişimci özelliklerinin geliştirilmesini sağlamak için ilkokul öğretim programlarından başlanarak öğrencilere girişimciliğin yararları fark ettirilmeli ve girişimci özellikler öğretilmelidir. $\mathrm{Bu}$ gerekçe ile girişimcilik kültürünün erken çocukluktan itibaren okullarda kazandırılması gerektiği düşünülerek farklı ülkelerin eğitim programlarında girişimcilik becerisine yer verilmiştir. İlkokul öğretim programlarında yer verilen girişimcilik kavramının kapsadığı özelliklerin, okullarımızda öğrencilere kazandırılması için öncelikle öğretmen adaylarına ve öğretmenlere bu becerinin kazandırılması ve bu konuda bilgi ve deneyim sahibi olmalarının sağlanması gerektiği söylenebilir. Bu da ancak Eğitim Fakülteleri'nde öğretmen adaylarına verilen eğitim ile sağlanabilir. Bu araştırmada, sınıf öğretmeni adaylarının "girişimcilik" becerisine ilişkin görüşlerinin ortaya çıkarılması amaçlanmaktadır. Çalışma nitel araştırma yöntemlerinden fenomenolojik yaklaşıma dayalı olarak desenlenmiştir. Araştırmaya Sınıf Öğretmenliği dördüncü sınıfta öğrenim gören 14 sınıf öğretmen adayı katılmıştır. Veriler yarı-yapılandırılmış görüşme formu ile toplanmıştır. Verilerin analizinde betimsel analiz tekniğinden yararlanılmıştır. Araştırma sonucunda öğretmen adaylarının girişimcilik kavramını "dikkat çeken", "kendine güvenen", “donanımlı", "lider", "üretken", "yeniliklere açık", "aktif”, "risk alan” kişilik özellikleri ile açıklamışlardır. Sınıf öğretmeni adaylarının, kendine güven, firsatları görme ve değerlendirme, duygusal zekâ gibi girişimciliğe ilişkin boyutları yaşamlarında daha sıklıkla yer verdikleri sonucuna ulaşılmıştır. Ayrıca sınıf öğretmeni adaylarının girişimciliğe ilişkin risk alma, yeniliklere açı olma ve lider olma gibi özelliklerini yaşamlarında kullandıkları sonucuna ulaşılmıştır.

Anahtar Sözcükler: Girişimcilik, 21. yüzyıl becerisi, sınıf ögretmeni adayl, yeterlik algısl.
Abstract: Upbringing individuals who possess "entrepreneurship" skills, which is mentioned under both life skills and 21 st century skills, is aimed in the education of almost all countries. In order to develop students' entrepreneurship skills, it should be ensured that the benefits of entrepreneurship are recognized and related skills should be taught starting from primary school curriculums. For this reason, entrepreneurship skill is included in the education programs of many countries, considering that entrepreneurship culture should be given in the schools starting from early childhood. Consequently, it can be said that in order to give the features of entrepreneurship concept that is included in primary school curriculum, this skill should first be given to pre-service teachers and teachers and ensured that they get knowledge and experience on this issue. Meanwhile, providing knowledge, skill and attitudes through entrepreneurship education introduced the need for giving entrepreneurship education in a consistent and thorough manner through curriculums. The method used in this study, which aimed to reveal the perception of pre-service teachers about entrepreneurship concept and their self-perception in terms of using entrepreneurship skills, is phenomenology, which is a qualitative research method. A total of 14 pre-service class teachers were participated in the study. The data of this research that was performed for revealing the experiences of pre-service class teachers were collected through semi-structured interviews. Descriptive analysis technique was used for the analysis of research data. Preservice class teachers have tried to explain entrepreneurship concept through personality traits, such as striking, selfconfident, leader, creative and productive, open to innovations, active, well-equipped and taking risks. It has been concluded that the dimensions of entrepreneurship, such as self-confidence, seeing and seizing the opportunities, emotional intelligence are more frequently present in the lives of the pre-service teachers who has participated in the research. However, in another research it has been concluded that teachers' self-confidence and selfefficacy are quite low in terms of entrepreneurship.

Keywords: Entrepreneurship, 21 st. century skills, preservice class teachers, self-efficacy perception

\footnotetext{
${ }^{1} \mathrm{Bu}$ çalışmanın bir bölümü 11-14 Mayıs 2016 tarihleri arasında Muğla'da düzenlenen XV. Uluslararası Sınıf Öğretmenliği Sempozyumu'nda sözlü bildiri olarak sunulmuştur

${ }^{2}$ Doç.Dr. Eskişehir Osmangazi Üniversitesi, Eğitim Fakültesi Temel Eğitim Bölümü, Sınıf Öğretmenliği ABD, ssanagun@ogu.edu.tr

${ }^{3}$ Yrd.Doç.Dr. Ömer Halisdemir Üniversitesi, Eğitim Fakültesi Temel Eğitim Bölümü, Sınıf Öğretmenliği ABD, natalay@ohu.edu.tr
} 


\section{Giriş}

21. yüzyıl toplumunda küreselleşme olgusu ile birlikte bilgi hızlı bir biçimde yayılmakta ve çok sayıda insana kısa sürede ulaşabilmektedir. Değişim ve dönüşüm çok hızlı bir biçimde insan yaşamına girmektedir. Bu anlamda bireylerin meydana gelen değişimlere uyum sağlaması, teknolojiyi takip edebilmeleri, hızla üretilen bilgi yığınları arasından kendileri için gerekli olan bilgiyi seçerek, analiz edip değerlendirebilmeleri, elde ettiği bilgiyi günlük yaşamda kullanabilmeleri beklenmektedir.

21. yüzyılda bireylerden yaşam boyu öğrenmeyi alışkanlık haline getirme farklı disiplinlerdeki bilgiye erişebilme, onları kullanma, çözümleme ve yapılandırma becerilerine sahip olma karşılaşılan problemlere ilişkin çözüm üretebilme, aynı zamanda yeni ve farklı fikirlere açık ve istekli olma ve yenilikçilik özelliklerini sergileyebilme gibi becerilere sahip olması beklenir (P21, 2009). Bilgi toplumunda bireylerin sahip olmas1 gereken bu beceri ve yeterlilikler 21. yüzyıl becerileri olarak adlandırılmaktadır. 21. yüzyıl becerileri (Partnership for 21st Century Skills [P21], 2009) göre ögrenme ve yenilenme becerileri başlığında yaratıcılık ve yenilenme, eleştirel düşünme ve problem çözme, işbirliği ve iletişim becerileri; yaşam ve kariyer becerileri başlı̆ğnda, esneklik ve uyum yeteneği, girişim ve öz-yönetim, sosyal ve kültürlerarası beceriler, liderlik ve sorumluluk; bilgi medya ve teknoloji becerileri başlığında, bilgi okuryazarlığı, medya okuryazarlığı ve teknoloji okuryazarlığı alt başlıkları ele alınmaktadır.

21. yüzyıl becerilerinin yaşam ve kariyer becerisinin alt boyutunda ele alınan girişimcilik kavramının tanımı ile ilgili alanyazında farklı tanımlamalar bulunmaktadır. Başlangıçta Cantillon (1730), Say (1803), Schumpeter (1934) ve Kirzner (1979) gibi ekonomistler tarafindan ekonomi teorisinde kavramlaştırılmış ancak daha sonra sosyoloji, psikoloji ve yönetim gibi diğer alanlarda da bu kavram ilgi çekmeye başlamıştır (Curth, 2011). Cantillon' göre girişimci bireyin rasyonel bir kararla risk alarak yeni bir girişime yönelmesi beklenir. Burada önemli olan girişimci bireyin risk alabilmesidir (Carland ve diğerleri, 1984:355; Akt. Yıldız ve Kapu, 2012). Tanım zaman içerisinde diğer araştırmaların da literatüre katkısıyla yenilik yapabilme ve firsatları değerlendirme boyutlarının ön plana çıkmasıyla başlangıca göre nispeten farklılaşmıştır (Özdevecioğlu ve Karaca, 2015). Son on yılda girişimciliğe yönelik yapılmış çalışmalar geniş bir vizyonda ele alınarak geliştirilmiştir. Bazı eğitim kurumlarının sonuçlandırılmış raporları girişimcilik eğitimini araştırması, teorik temelleri keşfetmesi, uygulamanın etkililiğini ortaya koyması açısından çok dikkat çekmiştir (Curth, 2011).

Girişimcilik eğitimi, öğrencilere yeteneği ve vizyonu nasıl birleştirecekleri ve farklı firsatlara nasıl dönüştüreceklerine ilişkin her türlü deneyimden oluşmaktadır. Bu yaratıcılığın ötesinde, sosyal değişimleri sezmek ve cevap verme yeteneğinin artırılması ile ilgilidir. Aynı zamanda öğrencilerin yaratıcılıklarını kullanmaları ve geliştirmeleri, ön ayak olma, sorumluluk ve risk alma gibi eğitim ve öğretim sürecidir. Girişimcilik eğitimi, iş odaklı görünüyor olsa da teşebbüs (girişim) eğitimi gibi algılanmamalıdır (Unesco, 2008). Girişimcilik eğitimi dar anlamda öğrencileri iş dünyasına hazırlama olarak tanımlanırken, geniş anlamda insanların yaşamlarının her alanında kullanabilecekleri bireysel, sosyal ve ekonomik getiri sağlayacak bir dizi yeteneğin kazandırıldığı süreç olarak tanımlanmaktadır (European Commission, 2011). 
Girişimcilik bilgi, beceri ve davranış/duygusal tutum ile geniş bir yelpazede ele alınabilecek insani bir olgudur. $\mathrm{Bu}$ olgu öğrenme süreçlerinin yanı sıra diğer süreçlerle beslenerek gelişir (Curth, 2011). Yamada (2004) girişimcilik kavramını geniş bir gözden geçirdikten sonra, girişimci rol ve işlevlerinin bölgesel bağlamda, sivil, sosyal ve kültürel faktörleri içeren çok boyutlu bir görünüm sunduğu sonucunu ortaya koymuştur (Chand ve Amin-Choudhury, 2006). Girişimcilik, aslında ağırlıklı olarak ekonomik anlam taşıyan bir kavram olsa da, günümüzde de sosyal boyuta sahip olduğu kabul edilmektedir (Chell, 2007; Akt. Yazıcı, Uslu ve Arık, 2016). Girişimcilik, ekonomik, sosyal, kültürel, teknolojik, psikolojik, kişilik özelliklerin ve demografik unsurların birleşmesiyle, aynı zamanda bireylerin yüksek bir girişimcilik motivasyonuna ve girişimcilik ruhuna sahip olmalarıyla ve girişimcilik faaliyetlerine isteklilik göstermeleriyle ortaya çıkmaktadır (İşcan ve Kaygın, 2011: 276). Vizyon sahibi, hırslı ve yaratıcı niteliği sahip bu bireylerin özellikleri, geçmiş yaşantılarına (aile, erken çocukluk eğitimi, akranlar, yerel toplum) bağlıdır (Curth, 2011). Başarılı girişimcileri belirlemede bireysel farkl11ıklar üzerinde durulmalı, bireyin önceki iş deneyimi, başarı ihtiyacı, üstün sosyal beceriler ve kişisel kararlılık gibi bireysel faktörlerde dikkate alınmalıdır (Çavuş ve Akgemici, 2008). Girişimci kişilik özellikleri bakımından yapılan araştırmalarda üç özellik üzerinde fikir birliğine varılmıştır. Birincisi, kendi yaşam tarzını değiştirme tercihini kendi elinde tutabilme, ikincisi kendisinin ve çevresindeki kaynak ve yetenekleri organize ederek sosyal, ekonomik ve kişisel çerçevede anlamlı değerler üretebilme üçüncüsü, hayal gücünü kullanarak problemleri çözebilme ve tüm bunların karşılığında ödül ve başarısızlığı göze alabilmektir (Top, 2012).

Girişimcilik konusunda yapılan çalışmalarda en fazla vurgu yapılan boyutların; risk alma, yenilikçi olma, kendine güven, firsatları görme, başarı isteği, motive olma, duyguları kontrol edebilme, karar verme ve özdenetim faktörlerini içine alan duygusal zekâ olduğu söylenebilir (Deveci ve Çepni, 2015). Öğretmen adaylarına yönelik geliştirilen ölçeklerde (Konaklı ve Göğüş, 2013; Yılmaz ve Sünbül, 2009) firsatları görme, başarı isteği, motive olma, duyguları kontrol edebilme, karar verme ve öz-denetim faktörlerini içine alan, ancak duygusal zekâ boyutunun ihmal edildiği görülmektedir. Literatürde görülen bu eksiklikten dolayı öğretmen adaylarının girişimcilik yeterlik algıları, risk alma, yenilikçi olma, kendine güven, firsatları görme ve duygusal zekâ boyutları ele alınarak belirlenmeye çalışı1mıştır.

Günümüzde artan nüfus sonucunda ortaya çıkan ve gelecekte de büyüyeceği öngörülen işsizlik sorunu karşısında, erken yaşlardan itibaren bireylerin istihdam edilmelerini sağlayacak özelliklerle yetişerek donanımlı olmaları anlayışı gündemdedir (Deveci, Zengin ve Çepni, 2015). Öğrencilere girişimcilik becerisinin verilmesindeki temel neden, kendileri ve öğrenmeye daha fazla sorumluluk almalarını, bireylerin yaşam amaçlarına ulaşmak için başarılı ve yaratıcı olmayı, mevcut firsatları keşfetmelerini sağlamaktır (Seikkula, 2008). Öğrenciler tarafından öğrenilen ve uygulanabilir olan bilgi, beceri, yetenek ve tutum üzerine girişimci özelliklerin gelişimi sağlanmaktadır. Yaşamlarında başarılı olmak isteyen bireylerin girişimci zihniyet yapısında olması gerekir (Ememe, Ezeh ve Ekemezie, 2013). Girişimciliğin başarılı olabilmesi için, eleştirel düşünme, iyi iletişim, takım halinde etkili çalışma gibi davranışsal becerilere de ihtiyaç duyulmaktadır. Değişim karşısında yaratıcılık, risk alma ve esneklik gibi kavramların giderek daha önemli hale gelmektedir (Uzoka ve Adetayo, 2008). 
Geniş kapsamda ele alınan bilgi beceri ve tutumların girişimcilik eğitimi ile verilmesi, ulusal öğretim programlarıyla girişimcilik eğitiminin tutarlı ve kapsamlı bir biçimde verilmesi ihtiyacını ortaya çıkarmıştır (Curth, 2011). Avrupa Komisyonu tarafından yayınlanan yeni bir rapora göre Avrupa ülkelerinin birçoğunda girişimcilik eğitimi her geçen gün daha fazla desteklenmektedir. Sekiz ülke (Danimarka, Estonya, Litvanya, Hollanda, İsveç, Norveç, Galler ve Belçika’nın Flaman kısmı) girişimcilik eğitiminin geliştirilmesi amacıyla özel stratejiler uygulamaya koymuş 13 ülke ise (Avusturya, Bulgaristan, Çek Cumhuriyeti, Finlandiya, Yunanistan, Macaristan, İzlanda, Lihtenştayn, Polonya, Slovakya, Slovenya, İspanya ve Türkiye) bu eğitimleri ulusal yaşam boyu öğrenme, gençlik ya da büyüme stratejilerinin bir parçası olarak uygulamaktadır. Avrupa ülkelerinin yarısı, girişimcilik eğitiminin güçlendirilmesini de kapsayan bir eğitim reformu sürecine girmiştir (Avrupa Komisyonu Raporu, 2012). Nitekim MEB 2013 fen bilimleri öğretim programında girişimcilik yaşam becerilerinin bir alt boyutunda ele alınırken MEB 2015 Hayat Bilgisi öğretim programında girişimciliğe temel becerilerin bir alt boyutunda yer verilmiştir. (MEB, 2013; MEB, 2015).

İlkokul öğretim programlarında girişimciliğe yönelik çalışmalarının olması ihtiyacı, öğrencilerin gelecekte karşılaşabilecekleri durumlara karşı güven ve özgüven içinde olmalarını sağlayan yöntemlerden biridir (Ememe, Ezeh ve Ekemezie, 2013). Öğrencilerin girişimci özellikleri kazanmalarında öğretmenlerin rolü önemlidir. Argon ve Selvi’ye ( 2013) göre bilgi çağının öğretmenleri, bilgiyi üretebilen, kullanabilen, sunabilen ve yönetebilen olması gerektiği gibi okullarındaki boşlukları görebilen ve değerlendirebilen, riske girebilen, kendine güvenen, yenilikçi, bağımsız ve üst düzey girişimcilik değerlerine sahip bireyler olmalıdır. Peltonen (2008) öğrencilerin arasında girişimciliğin gelişmesi gerekiyorsa öğretmenlerin daha girişimci olmalarının hayati önemine vurgu yapar. Bu bağlamda öğretmenlerin girişimciliği nasıl anlamlandırdığı, nasıl önemsediği ve yeni yöntemlere uyarmaya istekliliği önemlidir (Backstöm-Widjesog, 2008; Kyrö \& Carrier, 2005; Paajanen, 2001; Akt. Peltonen, 2008). Sınıf ortamında başarılı bir biçimde girişimcilik özelliklerinin uygulamaya aktarılmasında öğretmenlerin lisans eğitiminde girişimcilik eğitimi hakkında bilgi edinmiş olmaları gerekmektedir (European Commission, 2013). Lisans programlarında problem çözme, eleştirel düşünme ve iletişim kurma gibi uygulama becerilerini öğrencilere kazandırarak, mezun olduktan sonra kendi işlerini kuracak düzeye ulaşmalarını sağlamak amaçlanmaktadır (Beca, 2007). Girişimcilik özeliklerini ilkokul düzeyinde öğrencilere kazandıracak olan sınıf öğretmeni adaylarının, girişimcilik becerisine yükledikleri anlam ve girişimcilik becerisine ilişkin kendilerine yönelik algılarının ortaya konulması önemlidir.

$\mathrm{Bu}$ araştırmada, sınıf öğretmeni adaylarının girişimcilik kavramına ilişkin algıları ve girişimcilik becerisin kullanımında kendilerine ilişkin algılarının ortaya çıkarılmasını amaçlamaktadır. Bu kapsamda aşağıdaki sorulara yanıt aranmıştır:

- Girişimcilik kavramına ilişkin algıları (ifadeleri) nelerdir?

- Girişimcilik becerilerinin kullanımında kendilerine yönelik algıları nasıldır? 


\section{Yöntem}

Sınıf öğretmeni adaylarının girişimıilik kavramına ilişkin algıları ve girişimcilik becerilerinin kullanımında kendilerine yönelik algılarının ortaya konulması amaçlandığı araştırmada, nitel araştırma desenlerinden fenomenoloji (olgubilim) yaklaşımından yararlanılmıştır.

Bu desen kapsamında izlenen araştırma süreci Şekil 1'de verilmiştir.

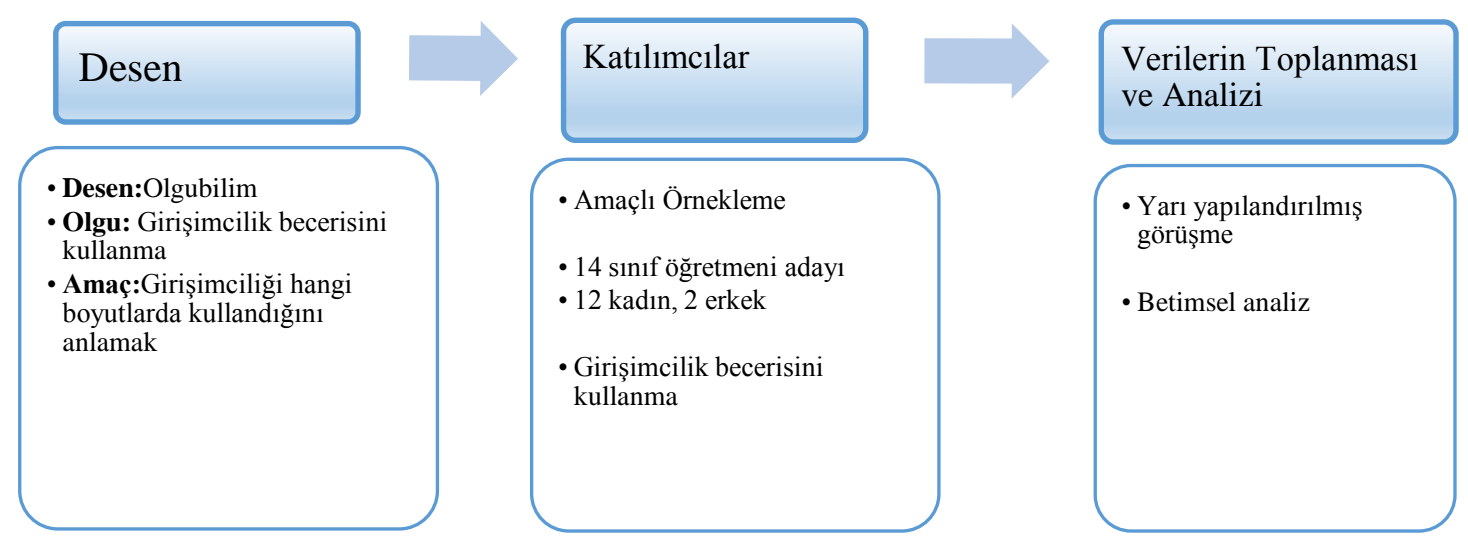

\section{Şekil 1. Araştırma Süreci}

Fenomenoloji (olgubilim) deseni, farkında olduğumuz ancak derinlemesine ve ayrıntılı bir anlayışa sahip olmadığımız olgulara odaklanır. Bu olgular yaşadığımız dünyada olaylar, deneyimler, algılar, yönelimler, kavramlar ve durumlar olabilir (Yıldırım ve Şimşek, 2011: 72). Bu araştırmada olgu, "girişimcilik algısı" olgusudur. Araştırmada sınıf öğretmenliği son sınıf öğrencilerinin girişimcilik algılarının, kavram ve kendilerini algılama boyutunda görüşme yapılarak derinlemesine incelendiği için nitel araştırma yaklaşımlarından fenomenoloji (olgubilim) yaklaşımı kullanılmıştır.

\section{Kat1limcilar}

Nitel araştırmalarda örneklem sayısı araştırmacının ne öğrenmek istediğine, araştırmacının amacına, neyin güvenilir ve kullanışlı olduğuna ve sahip olunan zaman ve kaynaklarda neler yapılabileceğine bağlıdır (Patton, 2002). Bu araştırmada amaçlı örnekleme yöntemlerinden ölçüt örnekleme kullanılmıştır. Amaçlı örnekleme, zengin bilgiye sahip olduğu düşünülen durumların derinlemesine çalışılmasına olanak tanımaktadır. Araştırmacı seçilen durumlar bağlamında doğa ve toplum olaylarını ya da olgularını anlamaya ve bunlar arasındaki ilişkileri keşfedip açıklamaya çalışır. Ölçüt örnekleme kullanılan araştırmalarda da gözlem birimleri belli niteliklere sahip kişiler, olaylar ya da durumlardan oluşturulabilir. Bu durumda örneklem için belirlenen ölçütü (temel nitelikleri) karşılayan birimler örnekleme alınırlar (Büyüköztürk ve diğerleri, 2009; Patton, 2002). Bu çalışmada katılımcıların belirlenmesinde katılımcıların araştırmaya gönüllü olmaları ve sınıf öğretmenliği programına ilişkin tüm dersleri alarak mezun duruma gelmiş olmaları olmak üzere iki temel ölçüt dikkate alınmıştır. Araştırmaya 2'si erkek 12'si kadın olmak üzere toplam 14 sınıf öğretmeni adayı katılmıştır. 


\section{Veri Toplama Araçları}

Sınıf öğretmeni adaylarının deneyimlerini belirlemeye yönelik yapılan bu araştırmada veriler yarı yapılandırılmış görüşme yolu ile toplanmıştır. Olgubilim araştırmalarında başlıca veri toplama aracı olan görüşme, olgulara yönelik yaşantıları ve anlamları ortaya koymayı amaçlar (Yıldırım ve Şimşek, 2011: 74). Görüşme, bir ya da daha fazla bireyin, belli amaçla birinin diğerine doğrudan bilgi aktardığı, sözel ve sözel olmayan iletişim araç ve tekniklerini kullanarak, sohbet havasında yapılan etkileşimdir (Bogdan ve Biklen, 2006).

Yarı yapılandırılmış görüşme tekniğinde araştırmacı görüşme formu olarak adlandırılan konu ile ilgili soruların yer aldığı bir listeye sahiptir. Araştırmacı, görüşmeciye görüşme formunda yer alan soruları sırayla sorar. Ancak görüşmecinin verdiği yanıtlar doğrultusunda görüşmeciye ek sorular sorabilir. Eğer görüşmeci belli soruların yanıtlarını başka soruların içerisinde yanıtlamış ise araştırmacı bu soruları sormayabilir. Yarı yapılandırılmış görüşme tekniğinde araştırmacı belli bir esnekliğe sahip olduğu için görüşme sorularının hangi sırayla, nasıl sorulacağı konusunda rahattır (Türnüklü, 2000). Araştırma kapsamında öncelikle alan yazın taranarak görüşme soruların yer aldığ1 görüşme formu hazırlanmıştır. Görüşme formunu geliştirme aşamasında uzman görüşleri alınarak görüşme formunun araştırma amaçlarına uygun olmasına çalışılmıştır. Görüşme sorularının işlevselliğini belirlemek içim iki sınıf öğretmeni adayı ile ön görüşme yapılmıştır. Ön deneme amacıyla gerçekleştirilen görüşme, araştırma kapsamı dışında tutulmuştur.

\section{Verilerin Çözümlenmesi}

Araştırma verilerinin çözümlenmesinde betimsel analiz tekniği kullanılmıştır. Betimsel analizde, elde edilen veriler, daha önceden belirlenen temalara göre özetlenir ve yorumlanır. Görüşülen ya da gözlenen bireylerin görüşlerinin çarpıcı bir biçimde yansıtmak amacıyla doğrudan alıntılara yer verilir (Yıldırım ve Şimşek, 2011). Araştırmada her bir soruya verilen yanıtların dökümü yapılmıştır. Verilerin dökümünden sonra veri analiz çerçevesi olarak görüşme sorularının kullanılmasına karar verilmiştir. Görüşme sorularına paralel olarak temalar oluşturulmuştur. Her bir görüşme sorusuna ait öğretmen adaylarının yanıtları, oluşturulan temaların altına yazılıp görüşme kodlama anahtarı oluşturulmuştur. Görüşme kodlama anahtarında, görüşme yapılan öğretmen adaylarının tümünün görüşlerini yansıtan temaların ilgili sorular altında seçenek olarak sıralanmıştır. Her bir araştırmacı birbirinden bağımsız olarak görüşme formlarını ve görüşme kodlama anahtarının işaretlenmesi, görüşme yapılan öğretmen adayının görüşüne uygun bulunan seçeneğin ilgili görüşme kodlama anahtarına işaretlenmesi biçiminde yapmıştır. Araştırmacıların görüşme kodlama anahtarına yaptıkları işaretlenmelerin tutarlılığını belirlemek amacıyla her sorunun yanıtı tek tek kontrol edilerek "Görüş Birliği”" ya da "Görüş Ayrılığı" biçiminde işaretlemeler yapılmıştır. Araştırmacılar ilgili soruda aynı yanıt seçeneğini işaretlemişse nu duru "Görüş Birliği" olarak kabul edilmiştir. Araştırmacılar ilgili soruda farklı seçenekleri işaretlemişlerse bu durum "Görüş Ayrılığı" olarak kabul edilmiştir. Geçerlik ve güvenirliği sağlamak için Miles ve Huberman'1n (1994) güvenirlik formülü P (Uzlaşma yüzdesi)= Na (Görüş Birliği) / Na (Görüş Birliği) $+\mathrm{Nd}$ (Görüş Ayrılığı) x 100 kullanılarak hesaplanmıştır. Hesaplama sonucunda araştırmanın 
güvenirliği, birinci soru için $\% 90$, ikinci soru için $\% 100$, ortalama ise $\% 95$ olarak hesaplanmıştır. Güvenirlik hesaplarının \%70'in üzerinde çıkması, araştırma için güvenilir kabul edilmektedir (Miles ve Huberman, 1994). Burada elde edilen sonuç, araştırma için güvenilir kabul edilmiştir.

\section{Bulgular}

Sınıf öğretmeni adaylarının girişimcilik kavramına, ilişkin algıları ve girişimcilik becerisinin kullanımında kendilerine ilişkin algılarını ortaya çıkarmaya yönelik yapılan bu araştırmada verilerden elde edilen bulgular şekiller biçiminde gösterilmiş ve doğrudan alıntılara yer verilmiştir. Şekillerin içindeki sayılar frekansı belirtmektedir.

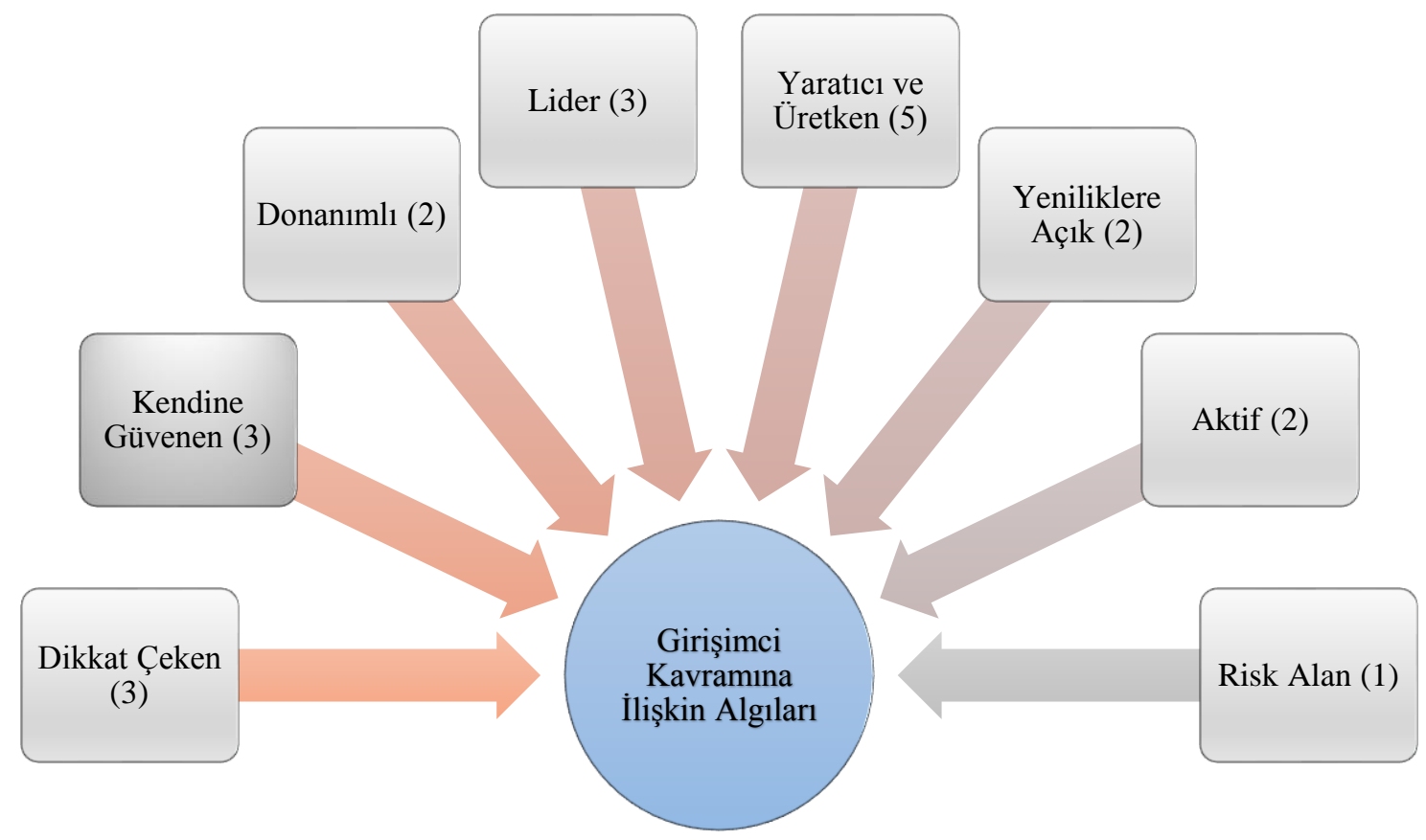

Şekil 2. Öğretmen Adaylarının Girişimcilik Kavramına İlişsin Algıları

Şekilde 2'de görüldüğü gibi, araştırmaya katılan sınıf öğretmeni adaylarının 3'ü "dikkat çeken”, "kendine güvenen” ve "lider olan” özelliği ile girişimcilik kavramını ifade etmişlerdir. Yine öğretmen adaylarının 5'i girişimciliği “yaratıcı ve üretken " ile 2'si “yeniliklere açık”, “ aktif olma "ve "donanımlı olma” durumu ile açıklarken "risk alan " alt teması ile ilgili öğretmen adayları bir görüş belirtmişlerdir.

Öğretmen adaylarından;

ÖA4 "Girişimci denilince kendine güvenen insan geliyor. Böyle her girdiği ortamda söyleyecek bir şeyi olan kendin güvenen insandir." ( kendine güven)

ÖA2 “ÖA2 “Girişimci deyince insanın özellikleriyle kıyasllyorum her defasında bir şeyleri yapabilen, bir ortama girdiğinde dikkat çekebilen insan geliyor aklıma" (dikkat çeken )

ÖA5 "Herhangi bir oluşuma ya da projeye adım atan ilk bunu düşünüp uygulamaya adım atan kişi." (lider) 
ÖA8 “Genel anlamda girişimcilik denilince herhangi bir alanda üretim yapmak bence. Bir olayın içine girişim var burada. Ya da yaptığınız çalışmayı herhangi bir şekilde geliş̧irmek olabilir.” (yaratıcılık ve üretken)

ÖA3 "Girişimci insan her alana bilgisi dâhilinde hâkim olmaya çalışan, donanımlı insandır." (donanimli)

ÖA12 "Girişimci yeni projelere adım atan, başarll olmaya çalışan, atak olan, kendi yolunu çizmeye çalışan, becerikli, aktif, yetenekli insandir." (aktif)

ÖA14 "Sürekli yeniliklere açık, kendini geliştirmeye çalışan, takıntılı olmayan kişsidir”. (yeniliklere açık)

ÖA1 “Girişimci insan eğer bir alanda kendini yeterli hissediyorsa sonuna kadar risk alır. Risk alarak kendi potansiyelini göstermeye çalışır.” (Risk alma)

biçiminde görüşlerini ifade etmişlerdir.

Sınıf öğretmeni adayları girişimcilik becerisinin kullanımında kendilerine ilişkin algıları altı alt temada değerlendirilmiştir.

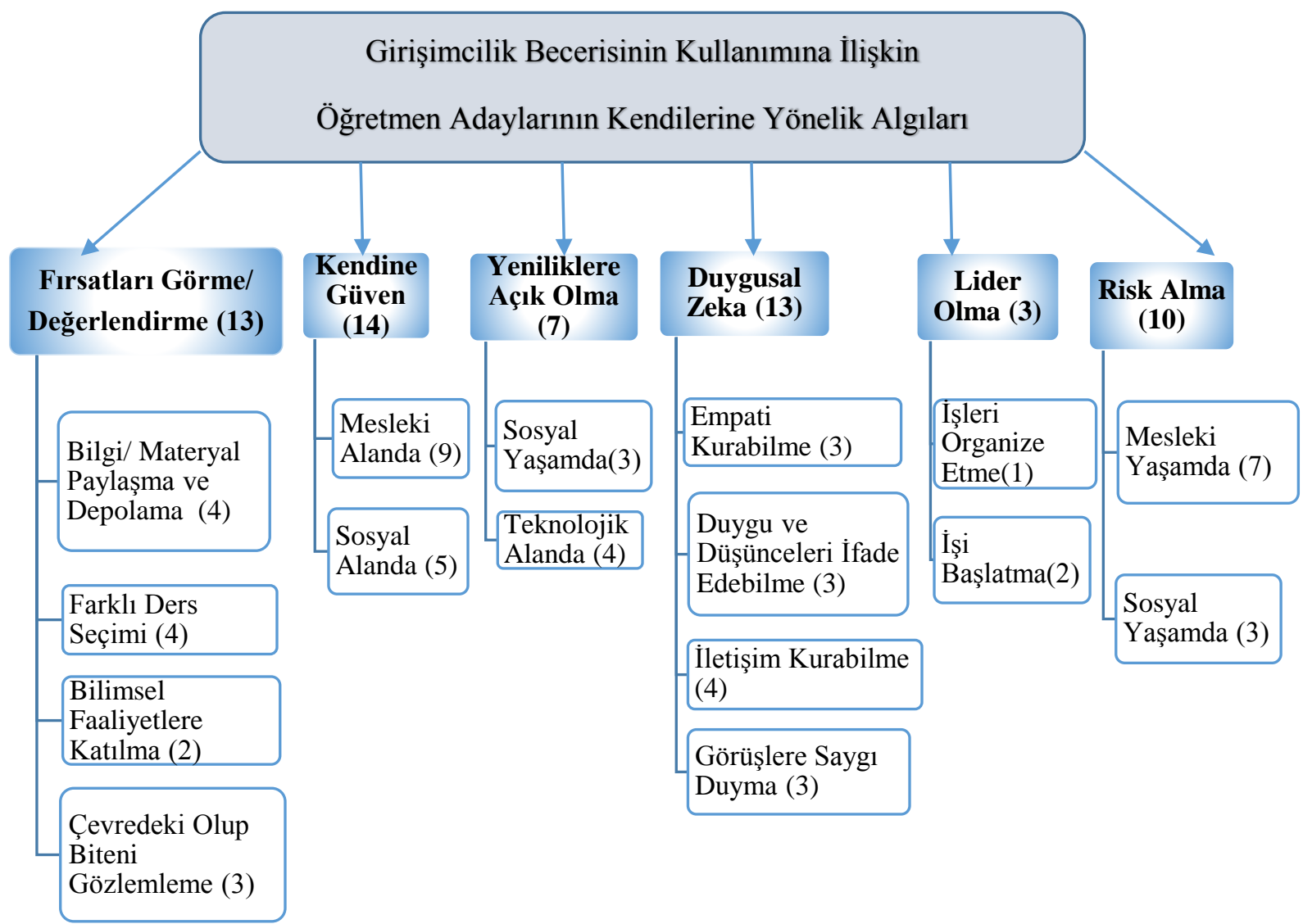

Şekil 3. Girişimcilik Becerisinin Kullanımına İlişkin Öğretmen Adaylarının Kendilerine Yönelik Algıları 
Şekil 3’te görüldüğü gibi 13 öğretmen adayının girişimciliğin bir alt boyutu olan firsatları görme ve değerlendirme becerisini: bilgi ve materyal paylaşımı ve depolama, farklı ders seçimi, kongre ve bilimsel faaliyetlere katılma ve çevredeki olup biteni gözlemleme biçiminde işe koştukları belirlenmiştir. Öğretmen adaylarından;

ÖA1 “ Ileride derslerde gösterebilmek için fotoğraflarım var. Mesela çeşitli yerlere gittim. İşte doğuda Mardin'e gittim. Orada çeşitli fotoğraflar çektim. Çeşitli yerler vardı. Onları gösterebilirim. Hala kaynak olarak elimde onlar var. Gittiğim yerleri o önemli yerleri sinıfta sergileyebilirim”

ÖA2 “Fen ve teknoloji dersi olsun ya da başka dersler olsun yaparken mesela arkadaşlarımız videoya alıyor. Ya da fotoğraflarımızı çekiyor. Ya da kendi hazırladı̆̆ımız sunumlarımız varsa videolar varsa ya da fen ve teknoloji dersinde hazırladĭ̆ımı simülasyonlar olsun, başka konularda hazırladıklarımız arkadaşlarımızla biz bunları bir araya getirip harmanlıyoruz."

ÖA7 “ Şöyle arkadaşlarımın sunumlarında dikkatimi çeken noktayı not alıyorum. İleride ders işlerken bunu uygulayabilirim ya da ögretmenimiz falan bize bir bilgi verdiğinde bu da aklımda dursun ileride atanırsam falan şurada kullanırım gibi düşünüyorum mesela ama böyle şeyler yapıyorum. Mesela arkadaşlar video falan kullanıyorsa bir yerde o videoları almaya çalışıyorum.

ÖA8 “Kendi yaptığım ödevleri ve arkadaşlarımın tüm ödevlerini facebook grubu gibi, gmail ile paylaşıyoruz. Bunları saklıyorum. Daha sonra öğretmenlerimizden aldı̆̆ımız kaynakları sakllyorum. Mesela karşıma çıkan görselleri, videoları ya da programları bunları saklayarak ilerliyorum genelde. Daha sonra arkadaşları var mesela başka fakültelerde okuyan onlarında sunum yaptıklarında sunumların alıp sakllyorum. Bana yarar sağlama bile ilerde herhangi bir konuyu işlerken elimin altında olması benim için kolaylık să̆lar”

biçiminde görüş bildirerek fırsatları, kendi olanaklarını farklı biçimlerde kullanarak değerlendirdiklerini ifade etmişlerdir.

Öğretmen adaylarından 9'u mesleki anlamda, 5'i sosyal anlamda kendine güven duyduğunu ifade etmiştir. Mesleki alanda kendine güvendiğini belirten öğretmen adaylarından;

ÖA5 “Aslında öğretim konusuna geldiğimiz de biraz çekincelerim acaba yapabilir miyim diye. Çünkü bir nesil yetiştiriyoruz. Ama bu staja gittikçe olacak yapacağız diye bir özgüven geliyor. Atandiğında aldiğım dersleri layıklyla vereceğimi düşünüyorum."

Mesleki anlamda olmasa da sosyal alanda kendilerine güvendiklerini ifade eden öğretmen adaylarından;

ÖA9 “ileride elimden geleni yapacağım en azından ne kadar yapabilirim o konuda kendime çok öz güvenim yok ama en azından kendimi geliştirmek için her zaman çaba harcadiğımı biliyorum ve bu yüzden rahatım içim rahat." 
Öğretmen adaylarından 7'sinin meslek ve sosyal yaşamda ve teknolojiyi kullanma bağlamında yeniliklere açık oldukları belirlenmiştir. Genel anlamda yeniliklere açık olduklarını belirten öğretmen adaylarının (vakit yetersizliği, ortam farklılığı, sınav... ) farklı nedenlerden dolayı yenilikleri takip edemedikleri görülmüştür. Öğretmen adaylarından;

ÖA1 "Kendimi İngilizce alanında biraz geliştiriyorum. Onun dâhilinde sosyal düşünürsek dans kurslarına gittim. Tiyatro eğitimi aldım işte öğrenciler için sınıf öğretmenliği için. Kitap okuyorum. Kitap okumayı bırakmıyorum. Yine öğrencilere kendimi daha gelişmiş bir öğretmen görsünler diye elimden geleni yapmaya çalışıyorum."

ÖA3 “ Ben 4 yıldır halk oyunlarındayım. Hatta dün akşam gösterim vardı. Onun dışında tepebaşı Belediyesinde dansçıyım. Odunpazarı gençlik merkezinin dansçıyım. Çünkü hocaları ortak.”

ÖA9 “Geçen yıl Türk halk müziği korosundayım. Gençlik merkezinin korosundayım. Burada da hatta şiir dinletisi çalışması yapmış̧ı geçen yll onlara katıllyorum. Şiir dinletisi. Arada işte böyle kitap okumak için bir yerlere gidiyorum. Sahaflara falan. Onun dışında açıkçası çift ana dala başladığımdan beri geçen yıl sadece müzikle ilgilenebildim koroyla".

ÖA10 “ Bir de benim takip ettiğim bir portalım var. Orada Türkçe sinıf ögretmenleriyle falan sohbet ettiğimiz fikir alışverişinde bulunduğumuz oluyor."

biçiminde mesleki ve sosyal yaşamda yenilikçi oldukları teknolojiyi de takip ederek bu becerilerini kullandıklarını ifade etmişlerdir. Yeniliklere açık olup farklı nedenlerle takip edemeyen öğretmen adaylarından;

ÖA11 "Yani dershane gidiyorum. O da vakit kalmadiğı için. İlk senelerde falan yani daha çok gezilere katılmaya çalıştım."

ÖA2 "Dediğim gibi ona pek fazla vakit ayıramıyorum. İşaret dili kursuna gitmeyi düşündüm. Ama onunda kayıt tarihleri farkl zamanlara denk gelmişti. Yakın zamanda tenis kursuna gitmeyi düşünüyorum. Ona kayıt olacağım. Onun dışında kendime ait bir tek hafta sonum oluyor. O zamanda arkadaşlarımla görüşüyorum ya da okulum çok yoğun olduğu zaman ödevlerimi yapıyorum"

biçiminde görüşlerini belirtmişlerdir.

Öğretmen adaylarından 13'ü duygusal zekâlarını farklı şekilde kullandıklarını ifade etmişlerdir. Ancak bir öğretmen adayının duygusal zekâ anlamında hiçbir ifade kullanmadığı belirlenmiştir. Öğretmen adaylarından;

ÖA7 "Böyle bir şey olduğu zaman acaba ben bu durumda ne yapardım diye ya da mesela karşımdaki insan özellikle konuşurken falan mesela bana bir şeyler söylüyorsa ben de kendimi ifade etmek için mesela sen benim yerimde olsaydın şöyle şöyle bir durumda ne yapardın falan diye. Özellikle bunun, bu özelliğimin gelişstiğini düşünüyorum". 
ÖA11 “Etkili bir şekilde iletişsim kurabildiği stajlarla beraber gördüm. Yani çocuklarla nasıl yakınlaşmam gerektiğini, nasıl davranmam gerektiğini. Okulda öğrendim birçoğunu çünkü önceden çocuklara karşı normaldim, normal yaklaşırdım. Fazla muhabbet etmezdim mesela. Ama şimdi okulda olunca görünce çocuklara nasıl davranman gerektiğini yavaş yavaş anllyorsun yani."

biçiminde görüşlerini ifade etmişlerdir.

Öğretmen adaylarından 3’ü farklı durumlarda lider olma durumunda bulunduklarını ifade etmişlerdir. Öğretmen adaylarından;

ÖA2 "Benim mesela lider bir kişilik özelliğim var ve bir şeyleri gerçekten organize etmeyi seviyorum ve bunu yapabildiğimi düşünüyorum. O yüzden bu tür etkinliklerde görev almak beni gururlandirlyor."

ÖA13 "Hep sorumluluğunu bilen bir iş yapılacaksa ilk adımı atan hep ben olurum. Ĕger bir grup çalışması yapılacaksa ben genelde liderlik boyutunda da yer alıyorum."

biçiminde görüş bildirerek liderlik anlamında ilk adımı atan kişi olduğunu ifade etmiştir.

Öğretmen adaylarından 7'si mesleki anlamda, 3'ü sosyal yaşamda risk alabileceklerini belirtirken diğer öğretmen adayları realist olduklarından hiçbir alanda risk alamayacaklarını ifade etmişlerdir. Öğretmen adaylarından;

ÖA1 "Farklı mesleğe yönelmek istemiyorum. İnşallah öyle bir şey olmaz. Ama Türkiye şartları gereği yine farklı bir şey olursa yine kendimi geliştiriyorum aslinda ben. İşte ne olur dershanecilik hayatı olabilir, özel ders olabilir. Ama bu mesleğe yönelik bir şey istiyorum. Onun dışında da imkânlar olmazsa illaki başka bir yerde de çalışılabilir."

ÖA 3 “ Sonunu düşünen hiçbir zaman kahraman olamaz. Boşver derdi. Ne olursa olsun derdi. Yani göze almaya bak derdi. Babam. Onun için hep göze almaya çalışıyorum. Yani sonunu düşünmeden hareket etmeye çalışlyorum."

ÖA12 "Tiyatro sahnesine hiçbir deneyimim olmadan çıkmam benim için bir riskti aslında. Çok çekingen bir insandım. Oyun gününe kadar çok heyecanlıyım. Birazdan oyun başlayacak hala çok heyecanliyım." biçimindeki ifadelerinden sosyal yaşamda risk alabildiklerini belirtmişlerdir".

biçiminde görüşlerini ifade etmişlerdir.

\section{Sonuç Tartışma ve Öneriler}

Araştırmaya katılan sınıf öğretmeni adayları girişimcilik kavramını "dikkat çeken”, "kendine güvenen”, “donanımlı”, “lider”, “üretken”, “yeniliklere açık”, “aktif”, "risk alan” kişilik özellikleri ile açıklamışlardır. Literatürde benzer biçimde girişimciliğe ilişkin kişilik özelliklerini, Gardner (1977), Hornaday (1971) kendine güvenen; Say (1803), Hornaday (1971), Kets de Vries (1985), Rauch ve Frese (2007) yaratıcl; Hornaday (1971) lider; Schumpeter (1950), Utsch, Rauch, Rothfu ve Frese (1999) yenilikçi; Cantillon( 1725), Shaver ve 
Scott (1991), Korunka vd. (2003), Steward ve Roth (2007) risk alan; Kets de Vries (1985), Shea (2014), Hornaday (1971) enerji (aktif olma) olarak belirlemişlerdir ( Kümbül Güler, 2010; Döm, 2012; Akt. Müftüoğlu ve Durukan, 2004; Akt. Yıldırım, 2013 ). Araştırmada sınıf öğretmeni adayları girişimciliği sadece kişilik özellikleri ile açıklamaya çalışmışlardır. Benzer biçimde Altan (2014) 'a göre de girişimcilik doğuştan genetik olarak insanda bulunan ancak yaşanılan kültürün ortaya çıkarmaya müsaade ettiği oranda ortaya çıkan bir olgudur. Ancak Mount (2009)'a göre de girişimcilik \%40 ‘1 doğuştan getirilen özelliklerle, \%60’1 ise sonradan kazanılan özelliklere ortaya çıkar (Akt. Altan, 2014). Bireyin sahip olduğu girişimcilik becerilerini desteklemek ya da geliştirmek yerine baskılayan ve bu becerilerin ortaya çıkarılmasına firsat tanınmayan bir ortam oluşturulursa kişinin bu özelliğini ortaya koyması oldukça zordur (Hisrich ve Peter, 2002). Her bireye özgü olan bireysel özelliklerin başarılı girişimci olma durumu ile arasında anlamlı bir ilişkinin olduğu sonucuna ulaşılmıştır (Antonio ve diğerleri). Bunun yanında yaş, aile tutumu, psikolojik faktörler gibi unsurlar da oldukça etkilidir (Deveci ve Çepni, 2014). Sınıf öğretmenlerinin girişimcilik kavramını sadece kişilik özellikleri bağlı kalarak yeterli düzeyde açıklayamadıkları söylenebilir. Benzer biçimde Bacanak (2013) fen bilgisi öğretmenlerinin girişimcilik kavramı hakkında yetersiz düzeyde bilgiye sahip oldukları sonucuna ulaşmıştır. Dolayısıyla öğretmen adaylarının bu konuda bilgi ve deneyim sahibi olmaları hem kişisel gelişimleri hem de gelecekteki meslek yaşamları için önemli görülebilir.

Araştırmaya katılan sınıf öğretmeni adaylarının, kendine güven, firsatları görme ve değerlendirme, duygusal zekâ gibi girişimciliğe ilişkin boyutları yaşamlarında daha sıklıkla yer verdikleri sonucuna ulaşılmıştır. Ancak başka bir araştırmada öğretmenlerin girişimcilik bağlamında özgüvenlerin ve öz yeterliklerinin düşük olduğu sonucuna ulaşılmıştır (Bacanak, Ülküdür ve Öner, 2012). Girişimcilik kavramının içerisinde yer alan kendine güven, sabır, engellerin üstesinden gelme, gayret, ısrar gibi pek çok özelliğe sahip olan öğretmen ve öğretmen adaylarının girişimci becerileri yüksek öğrenciler yetiştirebileceği söylenebilir (Bacanak, Ülküdür ve Öner, 2012).

Sınıf öğretmeni adaylarının girişimciliğe ilişkin risk alma, yeniliklere açık olma ve lider olma gibi özelliklerini yaşamlarında kullandıkları sonucuna ulaşılmışır. Sınıf öğretmeni adaylarının girişimciliğin farklı boyutlarını yaşamlarında kullandıklarını ifade etmeleri ile kendilerine ilişkin algılarının yüksek olduğu sonucuna ulaşılabilir. Benzer biçimde Ocak ve Su (2016) araştırmalarında kullandıkları ölçek ile eğitim fakültesindeki öğrencilerin yüksek puan elde etmeleri ile öğrencilerin girişimciliğe yatkın bireyler oldukları söylenebilir. Ancak Çelik (2014) eğitim fakültesinde sınıf ve sosyal bilgiler öğretmenliğinden 513 öğrenci ile ölçek aracılığ ile topladığı veriler ışığında, birinci ve dördüncü sınıf öğrencilerinin girişimcilik bilgi ve beceri düzeyleri açısından istatiksel olarak anlamlı bir fark olmadığı sonucuna ulaşmıştır. Bu bağlamda araştırma kapsamında aşă̆ıdaki öneriler verilebilir:

- Girişimciliğe ilişkin verilen dersler, proje üretme, sosyal gelişime ve yeniliğe açık öğretim uygulamaları biçiminde tasarlanabilir.

- Girişimcilik becerileri ile ilgili yapılan benzer çalışmalar farklı yöntem ve disiplinlerde desenlenebilir. 


\section{Kaynakça}

Altan, M. (2014). Türkiye'nin Eğitim Çıkmazı. Ankara: Pegem Akademi.

Antonio, T., Lanawati, S., Wiriana, T.A. \& Christina, L. (2014). Correation creativity, intelligence, personality and entrepreneurship achievement. The 5th Indonesia International Conference on Innovation, Entrepreneurship and Small Business (IICIES 2013)

Argon T. ve Selvi, Ç. ( 2013). İlköğretim okulu öğretmenlerinin sahip oldukları girişimcilik değerleri ve algıladıkları sosyal destek düzeyleri arasındaki ilişki. International Journal of Social Science. 6(1). 179206.

Avrupa Komisyonu Raporu (2012) Avrupa komisyonu basın açıklaması. http://europa.eu/rapid/pressrelease_IP-12-365_tr.htm adresinden 04.07.2016 tarihinde erişilmiştir.

Bacanak, A. (2013). Fen ve teknoloji dersinin öğrencilerde girişimcilik becerisinin gelişimine etkisi üzerine öğretmen görüşleri. Kuram ve Uygulamada Eğitim Bilimleri. 13(1), 609-629.

Bacanak, A. Ülküdür, M.A. ve Öner, F. (2012). Fen ve teknoloji dersi öğretmenlerinin girişimcilik becerisi ve etkisi ile ilgili görüşleri: nitel bir araştırma. http://kongre.nigde.edu.tr/xufbmek/dosyalar/tam_metin/pdf/2395-30_05_2012-15_47_45.pdf adresinden 14.06.2016 tarihinde erişilmiştir.

Beca, J. (2007). The need for improvement in innovativeness development and entrepreneurship training in highschool and university science education. T-Space at The University of Toronto Libraries, University of Toronto Mississauga. http://hdl.handle.net/1807/10112 adresinden 10.02.2016 tarihinde erişilmiştir.

Bogdan, R. C. \& Biklen, S. K. (2006). Qualitative Resarch For Education An Introduction to Theory and Methods. USA: Pearson International Edition.

Büyüköztürk, Ş., Kılıç Çakmak, E., Akgün, Ö. E., Karadeniz, Ş. ve Demirel, F. (2009). Bilimsel Araştırma Yöntemleri. Ankara: Pegem A Yayınları.

Chand, V.S. \& Amin-Choudhury, G. (2006). Teachers and socio-educational entrepreneurship: Competence as a consequence. The Journal of Entrepreneurship, 15 (2), 97-114.

Curth, A. (2011). Mapping of teachers' preparation for entrepreneurship education. http://www.ab.gov.tr/files/ardb/evt/1_avrupa_birligi/1_9_politikalar/1_9_4_egitim_politikasi/mapping en.pdf adresinden 02.06.2016. tarihinde erişilmiştir.

Çavuş, M.F. ve Akgemici, T. (2008). İşletmelerde personel güçlendirmenin örgütsel yaratıcılık ve yenilikçiliğe etkisi: İmalat sanayinde bir araştırma. Selçuk Üniversitesi Sosyal Bilimler Enstitüsü Dergisi, 20, 299231.

Deveci, İ. ve Çepni, S. (2014). Fen bilimleri öğretmen eğitiminde girişimcilik. Türk Fen Eğitim Dergisi, 11(2), 161-188.

Deveci, İ. ve Çepni, S. (2015). Öğretmen adaylarına yönelik girişimcilik ölçeğinin geliştirilmesi: geçerlik ve güvenirlik çalışması. International Journal of Human Sciences, 12(2), 92-11

Deveci, İ., Zengin M.N. ve Çepni, S. (2015). Fen tabanlı girişimcilik eğitimi modüllerinin geliştirilmesi ve değerlendirilmesi. Educational Sciences and Practice, 14 (27), 59-80.

Döm, S. (2012). Girişimcilik ve Küçük Işsletme Yöneticiliği. Ankara: Detay Yayınevi.

Ememe, O.N., Ezeh,S.C. \& Ekemezia, C. A. (2013). The role of head-teacher in the development of entrepreneurship education in primary schools. Academic Research International, 4 (1), 242-249.

European Commission, (2011). Entrepreneurship Education: Enabling Teachers as a Critical Success Factor "A report on Teacher Education and Training to prepare teachers for the challenge of entrepreneurship education. Final Report, Entrepreneurship Unit Bruxelles. 
European Commission, (2013). Entrepreneurship Education: A Guide for Educators. June 2013.Entrepreneurship and Social Economy Unit. European Union, 2013, Bruxelles.

İşcan, Ö. F. ve Kaygın, E. (2011). Potansiyel Girişimciler Olarak Üniversite Öğrencilerinin Girişimcilik Eğilimlerini Belirlemeye Yönelik Bir Araştırma. Organizasyon ve Yönetim Bilimleri Dergisi, 3 (2), 275 286.

Hisrich, R.D. ve Peter, M.P. ( 2002). Entrepreneurship. USA:Mc Graw-Hill/Irwin.

Konakl1, T. ve Göğüş, N. (2013). Aday öğretmenlerin sosyal girişimcilik özellikleri ölçeği: geçerlik ve güvenirlik çalışması. Gazi Üniversitesi Gazi Eğitim Fakültesi Dergisi 33(2), 373-391.

Korkmaz, O. (2012). Üniversite Öğrencilerinin Girişimcilik Eğilimlerini Belirlemeye Yönelik Bir Araştırma: Bülent Ecevit Üniversitesi Örneği. Afyon Kocatepe Üniversitesi İIBF Dergisi 14 (2), 209-226.

Kümbül Güler, B. (2012). Sosyal Girişimcilik. Ankara: Efil Yayınevi.

MEB. (2013). Fen bilimleri dersi (3, 4, 5, 6, 7 ve 8. sinuflar) öğretim programi. http://ttkb.meb.gov.tr/program2.aspx ?islem=1\&kno=213 adresinden 25.02.2016 tarihinde erişilmiştir.

MEB. (2015). Illkokul hayat bilgisi dersi 1,2 ve $3 . \quad$ sinfflar ögretim programı. http:// ttkb.meb.gov.tr/program2.aspx?islem=1\&kno=244 adresinden 25.02.2016 tarihinde erişilmiştir.

Miles, M. B. \& Huberman, A. M. (1994). Qualitative Data Analysis : An Expanded Sourcebook. Calif. : SAGE Publications.

Müftüoğlu, M.T. ve Durukan, T. ( 2004). Girişimcilik ve Kobi’ler. Ankara: Gazi Kitabevi.

Ocak, G. ve Su, A. (2016). An evaluation of entrepreneurship levels of prospective teachers. Asian Journal of Instruction 4(1), 1-16.

Partnership for 21st Century Skills. (2009). Framework for 21st century learning. http://www.p21.org/ourwork/p21-framework adresinden 12.10.2013 tarihinde erişilmiştir.

Patton, M. Q. (2002). Qualitative Evaluation and Research Methods. Thousand Oaks, CA: Sage Publications, Inc.

Peltonen, K. (2008). Can learning in teams help teacher to become more entrepreneurial? The interplay between efficacy perceptions and team support. LTA,3, 297-324.

Seikkula, L. (2008). Inter-regional seminar on promoting entrepreneurship education through curriculum reform. A paper presented at International Council for Small business world conference, Canada: Halifax Nova Scotia.

Shea, T. (2014). Educators stress entrepreneurial thinking during. saturday. http://www.cvilletomorrow.org/news/article/17804-educators-stress-entrepreneurial-thinking-duringadresinden 12.03.2016 tarihinde erişilmiştir.

Top, S. ( 2012). Girişimcilik Keşif Süreci. İstanbul: Beta Yayınevi.

Türnüklü, A. (2000). Eğitim bilim araştırmalarında etkin olarak kullanılabilecek nitel bir araştırma tekniği görüşme. Kuram ve Uygulamada Ĕ̌itim Yönetimi Dergisi, 24, 543-559.

UNESCO (2008). Inter-Regional Seminar on Promoting Entrepreneurship Education in Secondary School. http://unesdoc.unesco.org/images/0016/001600/160087E.pdf adresinden 02.02.2016 tarihinde erişilmiştir.

Uzoka, N. E. \& Adetoro, J. A. (2008). Capacity building through higher education: a panacea for youth employment in nigeria. 3rd Regional Conference on Higher Education for Youth Empowerment: opportunities, capabilities and second chances organized by Higher Education Research Policy and Network (HERPNET) at IITA, Ibadan, Nigeria. 
Yamada, J. (2004). A Multi-dimensional view of entrepreneurship: towards a research agenda on organisation emergence. Journal of Management Development, 21, 4, 289-320.

Yazıc1, K., Uslu, S. ve Arık S. (2016). The investigation of the social entrepreneurship characteristics of social studies pre-service teachers. Cogent Education, 3,1-11.

Yıldırım, Y. T. ( 2013). Girişim, Girişimci, Girişimcilik ve Risk Yönetimi Kavramları. Nazan Yelkikalan (Ed.), Girişimcilik içinde (s. 25-41). İstanbul: Beta Yayınevi.

Yıldırım, A. ve Şimşek, H. (2011). Sosyal Bilimlerde Araştırma Yöntemleri. Ankara: Seçkin Yayınları.

Yıldız, S. ve Kapu, H. (2012). Üniversite öğrencilerinin bireysel değerleri ile girişimcilik eğilimleri arasındaki ilişki: Kafkas Üniversitesi’nde bir araştırma. Kafkas Üniversitesi İktisadi ve İdari Bilimler Fakültesi Dergisi 3 (3), 39-66.

Yılmaz, E. ve Sünbül, A.M. (2009). Üniversite öğrencilerine yönelik girişimcilik ölçeğinin geliştirilmesi, Selçuk Üniversitesi Sosyal Bilimler Enstitüsü Dergisi, 21, 196-203.

\section{Extended Abstract}

Introduction

Upbringing individuals who possess "entrepreneurship" skills, which is mentioned under both life skills and $21^{\text {st }}$ century skills, is aimed in the education of almost all countries. In order to develop students' entrepreneurship skills, it should be ensured that the benefits of entrepreneurship are recognized and related skills should be taught starting from primary school curriculums. For this reason, entrepreneurship skill is included in the education programs of many countries, considering that entrepreneurship culture should be given in the schools starting from early childhood. The training of entrepreneurship skills consists of all kind of experiences about how to combine ability and vision, and how to transform it to various opportunities. This is beyond creativity; it is related to intuiting social changes and increasing response skills. At the same time, it is the process of training and educating students for improving and using their creativity, leading, taking responsibility and risks. Even though entrepreneurship education is seen as business-focused, it should not be perceived as enterprise (attempt) training. Consequently, it can be said that in order to give the features of entrepreneurship concept that is included in primary school curriculum, this skill should first be given to preservice teachers and teachers and ensured that they get knowledge and experience on this issue. Meanwhile, providing knowledge, skill and attitudes through entrepreneurship education introduced the need for giving entrepreneurship education in a consistent and thorough manner through curriculums. Therefore, it is important to reveal the meaning that pre-service class teachers assign to entrepreneurship skill and their self-perception on this issue, since they are the ones who will give entrepreneurship features to students at primary school level. This can only be achieved through the training that will be provided to pre-service teaches in education faculties.

\section{Method}

The method used in this study, which aimed to reveal the perception of pre-service teachers about entrepreneurship concept and their self-perception in terms of using entrepreneurship skills, is phenomenology, which is a qualitative research method. The phenomenon of this research is "entrepreneurship perception". 
Since the entrepreneurship perceptions of class teaching senior students were deeply examined in conceptual and self-perception dimensions through the interviews, phenomenology approach was used in the study. Criterion sampling, which is one of the purposed sampling methods, was used in the research. Two main criteria were taken into consideration; voluntarily participation in the research and being senior student of class teaching. A total of 14 pre-service class teachers, 2 men and 12 women, were participated in the study. The data of this research that was performed for revealing the experiences of pre-service class teachers were collected through semi-structured interviews. Descriptive analysis technique was used for the analysis of research data, in which obtained data were summarized and interpreted according to pre-defined themes.

Findings

Pre-service class teachers have tried to explain entrepreneurship concept through personality traits, such as striking, self-confident, leader, creative and productive, open to innovations, active, well-equipped and taking risks. Pre-service class teachers have evaluated their self-perceptions about using entrepreneurship skill under six sub-themes, namely seeing and seizing the opportunities, self-confidence, openness to innovation, emotional intelligence, leadership and taking risk. It has been found that 13 pre-service teachers have practiced "seeing and seizing the opportunities" sub-dimension by sharing knowledge and materials and storage, selecting different courses, participating in congress and scientific activities and observing what is happening in the surrounding. 9 of the pre-service teachers expressed confidence in the professional sense, whereas 5 of them expressed confidence in the social sense. 7 of the pre-service teachers were found to be open to innovation in their professional and social life, in terms of using technology. 13 of the pre-service teachers stated that they use their emotional intelligence in different ways. However, it was observed that one pre-service teacher has not used any statement for emotional intelligence. 3 pre-service teachers stated that they showed leadership in different occasions. 7 of the pre-service teachers said that they can take risks in professional sense, and 3 of them stated that they can take risks in social sense, whereas other pre-service teachers stated that they are realistic and they won't take any risk.

\section{Conclusion and Discussion}

It can be said that pre-service teachers cannot sufficiently explain entrepreneurship concept through personality traits. Researchers conducted in similar ways have also concluded that teachers have insufficient knowledge about entrepreneurship concept. Therefore, having knowledge and experience on this subject may be important for personal development and future professional life of pre-service teachers. It has been concluded that the dimensions of entrepreneurship, such as self-confidence, seeing and seizing the opportunities, emotional intelligence are more frequently present in the lives of the pre-service teachers who has participated in the research. However, in another research it has been concluded that teachers' self-confidence and self-efficacy are quite low in terms of entrepreneurship. 